\title{
REPUBLICANISMO NEO-ROMANO E DEMOCRACIACONTESTATÓRIA
}

\author{
Ricardo Silva
}

RESUMO

O artigo examina o conceito de democracia derivado da fórmula "neo-romana" da liberdade como nãodominação. Para os autores vinculados à tradição neo-romana, a realização do princípio republicano do povo como "guardião da liberdade" depende da constituição de um modelo de democracia contestatória, apresentado como superação dos modelos da democracia eleitoral e da democracia participativa - ambos considerados tributários de uma concepção positiva de liberdade. Após deter-se no exame do conceito de democracia contestatória, o artigo analisa as principais críticas a esse conceito. Duas objeções recebem destaque: a de que o racionalismo do modelo contestatório conduz à despolitização da deliberação democrática e a de que o excessivo zelo dos neo-romanos contra o populismo e a tirania da maioria reproduz os traços "elitistas" da tradição republicana clássica. Conclui-se com uma breve avaliação da pertinência dessas criticas.

PALAVRAS-CHAVE: republicanismo neo-romano; liberdade como não-dominação; democracia contestatória; elitismo; racionalismo; despolitização.

\section{INTRODUÇÃO}

É ambígua a relação da tradição republicana com a democracia ${ }^{1}$. Por um lado, mediante o princípio de que o que a todos concerne por todos deve ser deliberado e aprovado, o republicanismo estimula os ideais democráticos de extensão da cidadania e de incremento da participação popular na vida pública. Por outro, não é possível ignorar que tanto no que diz respeito à história política e institucional das cidades e Estados soi disant republicanos, como nos textos dos grandes teóricos do republicanismo, há inúmeras idéias e mecanismos institucionais que marcam o afastamento dessa tradição em relação ao governo popular. Exemplos não faltam.

Concebida como a principal fonte de inspiração do republicanismo moderno, a antiga repúbli-

\footnotetext{
1 Uma versão preliminar deste artigo foi apresentada no Seminário Temático "Teoria Política: instituições e ação política", ocorrido entre 25 e 29 de outubro no âmbito do $34^{\circ}$ Encontro Anual da Associação Nacional de Pós-Graduação e Pesquisa em Ciências sociais (Anpocs), em Caxambu (MG). Aos participantes do referido seminário, expresso meus agradecimentos. Sou grato também ao Conselho Nacional de Desenvolvimento Científico e Tecnológico (CNPq), que apóia com bolsa de produtividade a investigação que deu origem a este artigo.
}

ca romana é também muitas vezes retratada como um regime aristocrático destinado a conter e anular as pretensões democratizantes da plebe romana (ROULAND, 1997; MADDOX, 2002). As palavras de Cícero, o mais eminente ideólogo do republicanismo romano, são indícios da identidade aristocrática da constituição de Roma. No livro I da República, Cícero afirma - pela boca de Cipião, quando instado a escolher a melhor forma de governo - que "entre a impotência de um só e o desenfreamento da plebe, a aristocracia ocupou uma situação intermédia que, conciliando todos os interesses, assegura o bem-estar do povo [...]. Quanto à igualdade de direito ou da democracia, é uma quimera impossível" (CÍCERO, 2005, p. 4546). Mais: "colocar no mesmo nível o gênio e a multidão que compõem um povo, é suma iniqüidade a que nunca chegará um povo em que governem os melhores, isto é, em uma aristocracia" (ibidem).

O advento da época moderna não atenuou o ceticismo republicano em relação às vantagens do governo popular. Mesmo Maquiavel, talvez o mais pró-plebeu dos clássicos do republicanismo, não poupa a utilização de palavras de desconfiança, tais como "inveja", "licenciosidade", "ociosidade" e "ingratidão", para caracterizar as predisposições 
e "humores" do povo. Tampouco os republicanos ingleses do século XVII, tais como Harrington e Milton, malgrado sua rejeição à realeza, propugnaram a democracia como remédio para os males da política. O mesmo pode ser dito dos fundadores da república norte-americana, bastando que se tenha em mente seu profundo temor de uma eventual "tirania da maioria", decorrente do predomínio incontrastável da vontade da maioria.

Recentemente, porém, uma influente corrente de autores republicanos, inspirados na recepção maquiaveliana dos ideais da antiga república romana, vem procurando demonstrar que a relação ambígua que o republicanismo manteve historicamente com a democracia pertence ao passado. Se é verdade que em sua história pregressa o republicanismo não logrou êxito em afirmar sua vocação democrática, na atualidade, porém, a própria sobrevivência dos ideais republicanos não pode prescindir de sua reconciliação com a democracia. Autores como Quentin Skinner, Philip Pettit, John Maynor, Henry Richardson e outros têm argumentado que, nas condições das sociedades contemporâneas, a república propriamente compreendida só pode ser democrática e que a democracia tende à degeneração se não for republicana. Conforme assinalou recentemente um teórico neo-romano, referindo-se aos precursores de sua tradição, "os republicanos neo-romanos acreditavam que o povo representava o derradeiro controle sobre o poder do Estado e que qualquer versão moderna do republicanismo teria que se basear sobre uma visão da teoria democrática" (MAYNOR, 2003, p. 172).

Neste artigo, procurarei expor os contornos da teoria democrática articulada pelos principais expoentes da referida corrente de autores republicanos. Farei isso tomando como ponto de partida a concepção de liberdade elaborada pelo historiador inglês Quentin Skinner e pelo filósofo irlandês Philip Pettit. Para esses teóricos, é a noção de "liberdade como não-dominação" o aspecto realmente distintivo da tradição republicana, pelo menos da vertente que deita suas raízes mais profundas na experiência da antiga república romana e que, no alvorecer da época moderna, encontrou sua expressão paradigmática nas idéias de Maquiavel.

Veremos que os neo-republicanos favorecem uma teoria da democracia derivada do conceito de liberdade como não-dominação. Em tal teoria, a ênfase recai mais sobre os poderes negativos do povo do que sobre seus poderes positivos, ao mesmo tempo em que se valorizam mais as práticas de contestação do que a busca do consenso. Trata-se, segundo a denominação de seu principal arquiteto, de uma "democracia contestatória" (PETTIT, 1999).

No que segue, inicio indicando a especificidade da concepção neo-romana de liberdade em relação às concepções rivais do republicanismo inspirado no modelo da polis ateniense e do liberalismo. Em seguida, esboçarei os contornos do conceito de democracia derivado da concepção neoromana de liberdade, a democracia contestatória. Na seqüência darei atenção a um conjunto de críticas às pretensões democráticas dessa vertente da teoria política contemporânea. Veremos que tais críticas, em suas formulações mais radicais, insistem na denúncia da natureza "elitista" e "antipopular" do republicanismo; já em suas formulações mais moderadas, as críticas dirigem-se ao excessivo "racionalismo" inerente aos procedimentos deliberativos do modelo contestatório, um racionalismo cuja conseqüência mais saliente seria a "despolitização" da democracia.

\section{OS NEO-ROMANOS E A LIBERDADE}

Nas últimas décadas, vem-se observando um renovado interesse na tradição de pensamento político republicano. Embora a maior parte dos analistas do chamado republican revival ainda apresente esse movimento de idéias de maneira relativamente homogênea, parece-nos possível postular que há pelo menos duas grandes vertentes interagindo no âmbito do republicanismo, sem que com isso devamos concluir que a distinção analítica entre ambas corresponda a uma distinção essencial no movimento concreto do neorepublicanismo. Considerando suas vinculações mais remotas, uma vertente recorre aos ideais e instituições da antiga república romana, ao passo que a outra é inspirada no modelo da polis grega. Entre os grandes pensadores políticos da Antigüidade, a primeira elege Cícero como seu guia, a segunda, Aristóteles.

Até recentemente, em parte devido à influência dos estudos de Hans Baron (1966) e John Pocock (1975), essas duas vertentes do republicanismo apareciam de maneira pouco diferenciada nas reconstruções da história da tradição republicana. Baron e Pocock investigaram o ressurgimento dos sentimentos cívicos nas cida- 
des do Regnum Italicum do alto medievo e do início da era moderna. O pano de fundo do republicanismo renascentista, na versão desses autores, é a influência resultante da recuperação dos autores clássicos, especialmente de Aristóteles, naquele contexto. Embora também reconheçam a importância dos textos de Cícero na emergência dos ideais políticos das cidades italianas, deixam implícito que o pensamento político do Senador romano era, no essencial, derivado da sabedoria grega.

De um ponto de vista historiográfico, essa tese acerca da influência do modelo de Atenas sobre o republicanismo italiano tem sido questionada por Quentin Skinner e seus seguidores. Para Skinner, a redescoberta e a adaptação dos textos aristotélicos no contexto das cidades-repúblicas italianas serviram mais para confirmar a influência da filosofia moral e jurídica da antiga república romana do que para despertar um sentimento cívico até então adormecido entre os italianos. Assim, se a "a redescoberta do corpus aristotélico foi indubitavelmente de grande importância, ela não foi de modo algum tão crucial para a construção de uma completa defesa do autogoverno republicano quanto alguns estudiosos têm suposto" (SKINNER, 2002, p. 38). Na verdade, a redescoberta da tradição republicana nos primórdios da era moderna teria ocorrido mediante a ativação de duas fontes: o antigo direito romano, paradigmaticamente apresentado no Digesto compilado por ordem do Imperador Justianiano I em 533, e textos dos grandes historiadores e moralistas que viveram o período mais agudo de crise da República e ascensão do Império, dentre os quais se destacam nomes como os de Cícero, Salústio e Tito Lívio.

A polêmica historiográfica de Skinner com os neo-republicanos que encontraram em Atenas e em Aristóteles as raízes doutrinárias do republicanismo italiano - e do subseqüente republicanismo moderno - irradiou-se para o âmbito do debate teórico contemporâneo. Autores como Philip Pettit (1997) e John Maynor (2003), baseando-se nas narrativas do historiador inglês, argumentam que a distinção entre as modalidades neo-ateniense e neo-romana de interpretação da herança republicana clássica refere-se a uma disputa sobre o exato significado do conceito de liberdade que se encontra no núcleo do republicanismo.
Para teóricos contemporâneos mais próximos do modelo neo-ateniense, a liberdade republicana é aquela que surge no instante em que o cidadão transcende os interesses que o aprisionam na esfera privada e dispõe-se a agir em conjunto com seus concidadãos em benefício de toda a comunidade. Um indivíduo livre é, acima de tudo, um cidadão ativo. São exemplares as palavras de Arendt, para quem "A raison d'être da política é a liberdade, e seu domínio de experiência é a ação" (ARENDT, 1972, p. 192). Note-se que a participação política não consiste meramente em um meio, um instrumento para a constituição e manutenção da liberdade. A participação política voltada para o autogoverno da pólisé ela própria a liberdade. Trata-se, para usar a fórmula de Taylor (1985, p. 213), da liberdade como um "exerciseconcept", contrastante com a liberdade como "opportunity-concept", próprio da tradição libe$\mathrm{ral}^{2}$.

Como contraposição à perspectiva neoateniense, o modelo neo-romano da liberdade como não-dominação começa a ser articulado nos primeiros ensaios de Skinner sobre Maquiavel (SKINNER, 1983; 1984; 1990a; 1990b). Segundo Skinner, o conceito de liberdade do secretário florentino estava muito longe de corresponder à definição oferecida pelos neo-atenienses, chegando mesmo a afirmar, com exagero conducente a equívoco, que o modo pelo qual Maquiavel concebia a liberdade pouco se diferenciava da concepção hobbesiana, que define a liberdade como a ausência de oposição externa à ação dos indivíduos, uma concepção tipicamente negativa. A única diferença estaria em que Maquiavel "argumenta que o desempenho de serviços públicos e o cultivo de virtudes necessárias para desempenhá-los provam sob exame serem instrumentalmente necessários para evitar a coerção e a servidão, logo

2 John Pocock conectou de maneira mais direta a concepção aristotélica de liberdade com o espírito do republicanismo moderno, manifesto na fórmula conceitual do "momento maquiaveliano". No final de seu grande estudo sobre a tradição republicana, Pocock deixa claro que "em termos emprestados ou sugeridos pela linguagem de Hannah Arendt, este livro contou parte da história do renascimento no Ocidente moderno do antigo ideal de homo politicus (o zoon politikon de Aristóteles), que afirma sua existência e sua virtude por meio da ação política" (POCOCK, 1975, p. 550). Recentemente, o nexo entre o republicanismo aristotélico e a visão de Maquiavel foi explorado e reforçado por Pasquino (2009). 
sendo condições necessárias para assegurar qualquer nível de liberdade pessoal no sentido hobbesiano, ordinário, do termo" (SKINNER, 1984 , p. 217). Nessas primeiras escavações em busca da liberdade republicana, Skinner tendia a apresentar o conceito como uma hábil combinação entre liberdade negativa, manifesta na ausência de qualquer tipo de interferência nas escolhas individuais, e liberdade positiva, expressa na participação como instrumento necessário para proteger a área de livre atuação dos indivíduos. Era saliente a dificuldade de Skinner em especificar a diferença entre as concepções de liberdade negativa de republicanos e de liberais. Poderia mesmo a concepção de liberdade em Maquiavel ser compreendida "no sentido hobbesiano, ordinário, do termo"? Dificilmente. E Skinner deu-se conta disso. Em seus estudos mais recentes, o autor vem esforçando-se para introduzir um critério de distinção que faça da liberdade negativa republicana um conceito que represente algo diferente da simples ausência de oposição às escolhas individuais, pois aceitar essa definição seria o mesmo que aceitar que toda e qualquer limitação das escolhas dos indivíduos corresponde a uma afronta à liberdade. Nesse raciocínio, obviamente, a lei, ainda que justa e necessária, estaria em oposição à liberdade. As formulações atuais de Skinner vêm no sentido de bloquear essa conclusão. Seu interesse mais recente nas origens "jurídicas" da liberdade neo-romana (SKINNER, 1999), bem como sua constante mobilização do exemplo do instituto da escravidão como o paradigma da ausência de liberdade iluminam a relação de reciprocidade e complementaridade entre liberdade e lei. Trata-se de uma operação intelectual destinada a dissolver a oposição entre esses termos, derivada da concepção liberal de liberdade negativa.

Não há como deixar de perceber, nas inflexões de Skinner, a influência das formulações de Pettit (SILVA, 2008). A idéia-força do republicanismo de Pettit é um conceito de liberdade que, segundo o autor, não se deixa aprisionar em nenhum dos pólos da dicotomia "liberdade positiva - liberdade negativa”. Partindo da crítica à célebre formulação de Isaiah Berlin sobre os dois conceitos de liberdade, Pettit argumenta que "a taxonomia de Isaiah Berlin, de liberdades positiva e negativa, afasta uma terceira possibilidade mais ou menos saliente. Ele pensa em liberdade positiva como domínio de si próprio e em liberdade negativa como ausência de interferência alheia. Todavia, domí- nio e interferência não se equivalem. Então o que dizer da possibilidade intermediária, a de que a liberdade consista em uma ausência, assim como a concepção negativa, mas em uma ausência de domínio por outros, não em uma ausência de interferência? Essa possibilidade teria um elemento conceitual em comum com a concepção negativa - o foco na ausência, não na presença - e um elemento em comum com a positiva: o foco no domínio, não na interferência" (PETTIT, 1997, p. 21-22)

É decisiva, no argumento, a proposição de que o republicanismo sustenta-se em uma concepção negativa de liberdade, uma vez que esta se define pela ausência, não pela presença de algo. De um ponto de vista normativo, a negatividade da liberdade republicana dá guarida à preocupação dos liberais de evitar as conseqüências potencialmente ameaçadoras à liberdade individual, vinculadas às concepções positivas de liberdade. Contudo, o que deve estar ausente não é a mesma coisa para o republicanismo e para o liberalismo. Enquanto pensadores liberais como Isaiah Berlin estabelecem a necessidade da ausência de qualquer tipo de interferência intencional de terceiros como o critério da liberdade individual, Pettit destaca que não é qualquer forma de interferência intencional que se revela incompatível com a liberdade republicana, mas exclusivamente aquelas formas de interferência que podem ser qualificadas como arbitrárias. E interferência arbitrária, para o autor, é sinônimo de dominação. Daí a fórmula sintética da liberdade como ausência de dominação, ou, simplesmente, liberdade como não-dominação.

Comparado com o ideal da não-interferência, o ideal da não-dominação seria dotado de maior riqueza, tanto do ponto de vista sociológico, quanto do ponto de vista constitucional. Para demonstrar essa tese, Pettit nos convida a contemplar duas situações. A primeira seria aquela em que o ideal da não-dominação é capaz de vislumbrar o comprometimento da liberdade em circunstâncias em que o liberalismo enxergaria seu pleno gozo; e a segunda seria aquela em que o ideal da não-dominação admitiria a manutenção da liberdade em situações em que o liberalismo denunciaria a redução ou a supressão da mesma.

Para ilustrar a primeira situação, o exemplo mais recorrentemente apresentado por Pettit, exemplo retirado dos clássicos da tradição republicana, é 
aquele que configuraria a relação entre um senhor benevolente e seu escravo afortunado. Trata-se da situação em que o senhor pode realmente eximir-se de qualquer tipo de interferência na vida do escravo; pode permitir que seu escravo aja conforme lhe aprouver; e pode até mesmo fornecer meios para ampliar o leque de escolhas disponíveis ao escravo. Do ponto de vista de Berlin, essa situação não acarretaria afronta à liberdade do escravo, uma vez que, de fato, o escravo realiza suas ações sem nenhum tipo de interferência do senhor. Para Pettit, todavia, a liberdade negativa republicana requer não apenas que não haja interferência arbitrária de fato, mas também que nenhum dos pólos de uma dada relação mantenha um status que lhe permita interferir no outro conforme o arbítrio de sua vontade. Assim, por mais benevolente que seja o senhor, o escravo continuará sendo escravo e, enquanto tal, um objeto de dominação à mercê da vontade arbitrária de outra pessoa.

Com relação à segunda situação, o que Pettit tem principalmente em mente são as leis que condicionam as escolhas de todo e qualquer cidadão. Embora a lei seja um caso óbvio de interferência, contanto que ela se faça em consonância com os "interesses comuns assumidos" pelos indivíduos sobre os quais ela é exercida, ela representaria um tipo não arbitrário de interferência, não passível de ser considerado como dominação ou afronta à liberdade.

Se o ideal da não-dominação está relacionado à existência de determinado status, então o problema de como assegurar resiliência e perenidade a esse status garantidor da liberdade passa ser um problema central da polity republicana. Ao ater-se apenas a interferências efetivas, a perspectiva liberal desobriga-se de encaminhar soluções para as estruturas de dominação em que a interferência arbitrária não é plenamente visível, existindo apenas como potencial. E ao apresentar toda e qualquer forma de interferência intencional como antagônica à liberdade, ela inibe qualquer tipo de consideração sobre a lei como um meio para reduzir os níveis de dominação existentes na sociedade ${ }^{3}$.

3 Com efeito, até mesmo a forma específica de regime político mais condizente com o ideal da não-interferência é algo indeterminado. Não surpreende que um pensador como Isaiah Berlin não esteja disposto a reconhecer na democracia a forma de regime mais adequada para assegurar a liberdade. Nada na estrutura lógica do conceito de liberdade
Contrapondo-se a Berlin, Pettit é enfático ao defender a tese do papel constituinte da lei republicana no estabelecimento e preservação da liberdade dos indivíduos. Conforme as palavras do autor, "a linha seguida pelos republicanos aparece em sua concepção de liberdade como cidadania ou civitas [...]. A liberdade então é vista na tradição republicana como um status que existe apenas sob um apropriado regime legal. Tal como as leis criam a autoridade de que desfrutam os legisladores, elas também criam a liberdade que os cidadãos compartilham" (idem, p. 36).

$\mathrm{O}$ que decorre dessa formulação é a centralidade da função da lei como inibidora do exercício do poder arbitrário. De acordo com Pettit, há duas modalidades gerais de interferência arbitrária: o dominium e o imperium. A primeira refere-se à presença de dominação entre concidadãos, que ocorre quando indivíduos ou grupos de indivíduos encontram-se sob a ameaça da - ou sob a efetiva submissão à - vontade arbitrária de outros. A segunda refere-se à interferência arbitrária exercida pelos detentores do poder público sobre os cidadãos. Do ponto de vista do indivíduo, é tão pernicioso ser dominado por seus concidadãos quanto por governantes autocráticos e corruptos. Mas Pettit acentua que o domínio exercido por um indivíduo sobre outro na sociedade é mais facilmente sujeito à contestação, na medida em que o agente dominado pode apelar ao próprio Estado em sua defesa. A contestação é mais difícil de ocorrer quando o agente dominante é o próprio Estado. Por isso, "não adianta estabelecer instituições ou tomar iniciativas que reduzem a dominação associada ao dominium se esses mesmos instrumentos ensejarem o tipo de dominação associado ao imperium; o que se ganha de um lado será perdido - e talvez mais do que

como ausência de interferência impediria que um "déspota de inclinações liberais" cumprisse melhor a função de guardião da liberdade, pois “a liberdade nesse sentido não é incompatível com alguns tipos de autocracia ou pelo menos com a ausência de autogoverno" (BERLIN, 2002, p. 235). Conforme aponta Skinner: "Isso continua sendo uma distinção definitiva entre os proponentes de uma visão de política 'republicana' em contraste com a visão 'liberal'. Liberais são democratas em um sentido secundário: o que lhes importa é a extensão da liberdade, seja quem for que a conceda. Republicanos são antes e principalmente democratas: eles acreditam que a liberdade depende do autogoverno" (SKINNER, 2007, p. 110). 
perdido - no outro" (idem, p. 173). Como evitar que o Estado e suas leis, pretensos guardiões da liberdade, tornem-se fontes de dominação e de redução da liberdade dos cidadãos?

\section{DEMOCRACIA CONTESTATÓRIA}

Os teóricos neo-republicanos respondem a questão acima por meio da apresentação de um modelo que conjuga o constitucionalismo com a forma democrática por eles denominada democracia contestatória (PETTIT, 1997; MAYNOR, 2003; RICHARDSON, 2003). A conjugação desses dois princípios delineia os contornos da forma institucional do Estado republicano, apta a abrigar o ideal da liberdade como não-dominação.

Um regime constitucional voltado para a defesa da liberdade republicana e destinado a impedir o arbítrio dos governantes deve cumprir três condições essenciais: "A primeira condição é, na frase de James Harrington, que o sistema deve constituir um 'império de leis e não de homens'; a segunda, que deve distribuir os poderes legais entre diferentes partidos; e a terceira, que deve fazer uma lei relativamente resistente à vontade da maioria" (PETTIT, 1997, p. 173).

A primeira condição, cristalizada na idéia do regime constitucional como um "império da lei", depende de como a legislação é formulada e estabelecida. A lei deve ser de aplicabilidade universal e todo e qualquer cidadão, inclusive os próprios legisladores e governantes, devem submeter-se ao que ela prescreve. A lei deve também ser promulgada e levada ao conhecimento dos cidadãos antes de sua aplicação. Além disso, ela deve ser inteligível, consistente e relativamente resistente a mudanças ocasionais.

A segunda condição do constitucionalismo - a distribuição de poder - depende da dispersão de prerrogativas no âmbito das funções do Estado republicano. A forma mais conhecida dessa modalidade de distribuição de poder encontra-se no clássico instituto da independência entre os poderes Legislativo, Executivo e Judiciário. Para os neo-romanos, trata-se de uma modalidade de dispersão de poder herdeira da teoria do governo misto, protagonizada pela tradição republicana desde a Antigüidade Clássica. Na modernidade, pensadores como Maquiavel, Locke e Montesquieu a ela associaram-se, e outros, como Hobbes e Rousseau, combateram-na. A razão pela qual os republicanos têm defendido a diferenciação das funções de elaboração, execução e interpretação da lei é, conforme Pettit, mais ou menos óbvia, uma vez que "a consolidação de funções nas mãos de uma pessoa ou grupo seria semelhante a permitir àquela parte deter um poder mais ou menos arbitrário sobre as outras; isso significaria a possibilidade de manipular a lei de um modo relativamente desimpedido" (idem, p. 177). Também relevantes para a satisfação da condição de distribuição de poder são institutos como o bicameralismo, no âmbito do parlamento, e o federalismo, que viabiliza certo grau de autonomia dos governos locais em relação ao governo central.

A terceira condição do regime constitucional republicano - a condição contra-majoritária - destina-se ao estabelecimento de barreiras de contenção contra mudanças da lei decorrentes da flutuação dos humores das maiorias circunstancialmente representadas no poder. Neste particular, os neo-romanos investem contra a tradição de pensamento político e constitucional que localiza a legitimidade de determinada lei no fato desta contar com o suporte da maioria do povo. De acordo com Pettit, "a crença em proteções contra-majoritárias requer uma jurisprudência sob a qual uma boa lei - uma boa lei, não necessariamente uma lei como tal - é identificada por alguns outros critérios, que não pela medida de se ter o suporte da maioria". Ele sugere ainda que a boa jurisprudência, ao recusar as imposições das maiorias circunstanciais, deveria buscar legitimidade nos costumes que determinadas comunidades consolidaram ao longo de sua história, uma vez que a legislação decorrente dos costumes "tem sido historicamente testada por sua capacidade de responder à expectativa da comunidade e por sua capacidade, por assim dizer, de sustentar a liberdade como não-dominação" (idem, p. 182).

Pois bem, ainda que o constitucionalismo seja um elemento indispensável a uma república bem ordenada e à defesa da liberdade dos cidadãos, ele, por si só, não está completamente equipado para assegurar a realização de tais fins. O fato é que mesmo o mais bem detalhado arcabouço legal não pode ser minucioso o bastante para eliminar certa margem de poder discricionário nas mãos de determinados indivíduos ocupantes de posições de mando no governo. Conforme já assinalava o teórico republicano inglês Algernon Sydney, em 
meados do século XVII, "nenhuma lei pode ser tão perfeita que responda exatamente a cada caso que possa suceder" (Sydney apud ETTIT, 1997, p. 183). Além disso, mesmo que tal grau de detalhamento fosse possível, ele seria provavelmente indesejável, uma vez que certa margem de discricionariedade para a tomada de decisões é necessária, a fim de que as autoridades do poder Executivo e do Judiciário possam perseguir os objetivos de um Estado republicano. Nesse caso, a questão que permanece é a seguinte: como impedir que a discricionariedade dos governantes degenere em arbitrariedade contra o povo?

Os teóricos neo-romanos defendem a idéia de que a forma constitucional do republicanismo deve ser complementada pela "democracia contestatória", um conjunto de práticas e mecanismos institucionais que aponta para a reconciliação da liberdade negativa das pessoas particulares com a participação efetiva do povo nos assuntos públicos. A reconciliação é considerada possível porque a participação não é pensada como realização de determinada concepção de bem, como nas teorias da liberdade positiva, mas como meio efetivo de evitar-se o mal resultante da afronta à liberdade como não dominação. Conforme Maynor, "a contestação democrática republicana moderna é um modo atrativo para minimizar a dominação tanto na forma do imperium como do dominium", e uma das razões disso é que o "republicanismo moderno não procura oferecer respostas 'corretas' ou 'verdadeiras' tal como pretende o republicanismo neo-ateniense" (MAYNOR, 2003, p. 167)

Em sua definição mais elementar, a democracia refere-se ao controle popular sobre o governo do Estado. A noção de que o povo pode controlar o governo pressupõe a existência de algum nível de interesse comum reconhecível e assumido pelo conjunto de indivíduos e grupos em dada comunidade. Assim, um governo será tão mais democrático quanto mais as leis e as políticas governamentais seguirem os interesses comuns do povo. O papel normativo da democracia consiste em orientar o governo a seguir todos os interesses comuns da comunidade e somente tais interesses (PETTIT, 1997, p. 114). A democracia deve fornecer meios de evitar os "falsos positivos" e os "falsos negativos" (PETTIT, 1999; MAYNOR 2003). Ou seja, por um lado, ela deve prever mecanismos destinados a detectar e bloquear a aprovação de leis e políticas governamentais que, em- bora envoltos na aparência de instrumentos do interesse comum, não passam de expedientes habilmente manipulados por grupos e facções com vistas à satisfação de seus interesses facciosos. Por outro, a democracia deve contar com mecanismos que previnam a rejeição de leis e políticas que estariam, aparentemente e à primeira vista, em desacordo com a percepção imediata dos interesses comuns, mas que sob escrutínio mais cuidadoso revelam-se consistentes com o ideal da não-dominação.

Para os neo-romanos, a principal função do sistema eleitoral é impedir que os governantes ignorem deliberadamente os interesses comuns assumidos pelos cidadãos. Por meio de eleições periódicas, a maioria (absoluta ou relativa) dos cidadãos assume um papel "autoral" em uma república democrática. A coletividade exerce, ainda que indiretamente, sua vontade soberana na tomada de decisões públicas. Estando permanentemente sob os olhares vigilantes dos eleitores, os representantes que desejarem permanecer em seus cargos pensarão duas vezes antes de assumir pontos de vista particularistas, ignorando os interesses das maiorias eleitorais. Os candidatos a cargos públicos são constantemente pressionados a sondar e seguir tais interesses. Nas repúblicas contemporâneas, não há como falar em democracia ignorando a importância imperativa dos processos eleitorais.

Contudo, a democratização eleitoral não satisfaz todas as exigências do republicanismo democrático. Philip Pettit chama a atenção para uma insuficiência da democracia eleitoral em assegurar o status da liberdade política a todos os cidadãos. "A democracia eleitoral pode significar que o governo não pode ser completamente indiferente às percepções populares sobre os interesses comuns e que ele não pode falhar inteiramente em tentar promover tais interesses. Mas é plenamente consistente com a democracia eleitoral que o governo possa seguir apenas os interesses assumidos de uma maioria, absoluta ou relativa, sobre determinada questão e que isto possa resultar em dominação do ponto de vista dos outros" (PETTIT, 1997, p. 174).

A democracia eleitoral responde ao anseio do autogoverno do povo, mas isso não implica necessariamente a liberdade das pessoas. Além do povo em sua expressão coletiva ("o" povo que se autogoverna), o regime democrático deve servir 
ao povo como o conjunto de indivíduos considerados um a um em uma multiplicidade. A democracia eleitoral só tem olhos para o povo como coletividade autogovernante, não para as pessoas particulares que participam da vida em sociedade. Do ponto de vista do ideal da liberdade neoromana, "a eliminação da dominação requereria não apenas que o povo considerado coletivamente não possa ser ignorado pelo governo, mas também que o povo considerado separadamente ou atomizadamente não possa sê-lo" (idem, p. 178).

Daí a necessidade de estender-se o modelo republicano de democracia para além da democracia eleitoral, compreendendo também uma institucionalidade destinada a evitar que a vontade da maioria imponha-se a minorias e a cidadãos particulares de maneira arbitrária.

Considerando sua meta de assegurar o controle popular sobre os governantes e promover a realização do interesse comum assumido pelo povo, a democracia vislumbrada pelos neo-romanos é, em primeiro lugar, uma forma particular de democracia deliberativa. Para Richardson, "os cidadãos em uma democracia devem governar raciocinando uns com os outros. O autogoverno coletivo deve, portanto, ser racional. Assim, [...] a democracia deve ser fortemente deliberativa" (RICHARDSON, 2002, p. 73). O interesse comum não é um fato dado de antemão e capaz de expressar-se de modo objetivo. Sua explicitação pressupõe a existência de um amplo fluxo comunicativo entre os indivíduos afetados pelas decisões públicas. É exatamente esse fluxo comunicativo que torna possível conceber o conjunto dos indivíduos de uma população como um público. Isso ocorre quando os membros de uma população "transcendem seu fechamento individual. Eles conversam e trocam idéias sobre questões de preocupação comum, questões do momento político, e o fazem com algum propósito ou efeito" (PETTIT, 2004, p. 75). Esse intercâmbio de idéias sobre preocupações comuns com vistas a um propósito comum pressupõe um estoque de concepções e crenças que se estabelece como base do processo comunicativo. No entanto, não é a persecução do consenso o aspecto distintivo da versão neo-romana da democracia deliberativa. Mais importante que o alcance do consenso positivo entre os membros de uma comunidade é a possibilidade de ampla contestação das ações governamentais. "O que importa não é a origem histórica da decisão em alguma forma de consenso, mas sua responsividade modal ou contrafactual à possibilidade do dissenso" (PETTIT, 1997, p. 185). Assim, a primeira condição de uma democracia contestatória é que ela seja uma democracia fundada no debate racional. As decisões que se baseiam no processo deliberativo devem realizar-se sob regime de transparência, possibilidade de escrutínio, ampla liberdade de informação etc. Além disso, os governantes são constantemente instados a apresentarem as razões de suas decisões de modo a torná-las legítimas. A base deliberativa é a primeira condição da democracia contestatória.

Todavia, essa primeira condição não nos levará muito longe se as minorias existentes em dada comunidade não dispuserem dos meios necessários para se fazerem ouvir efetivamente nos fóruns apropriados do debate público. Audi alteram partem (ouve a outra parte) é a divisa retórica dos neo-romanos. Por isso, é necessário satisfazer a segunda condição da democracia contestatória: a inclusão de todos os pontos de vista razoáveis no processo deliberativo. A institucionalidade democrática deve estar preparada para assegurar que os mais diversos grupos sociais, especialmente os grupos alijados das maiorias circunstanciais, contem com a presença de seus representantes diretos nos fóruns deliberativos (MAYNOR,2003). São justificáveis medidas que promovam a inclusão de tais setores no debate público (PETTIT, 1997, p. 191). A inclusão dos diferentes grupos relevantes da sociedade deve dar-se tanto no âmbito do parlamento, quanto no âmbito do poder Judiciário e do Executivo. Formas de ações afirmativas para corrigir a sub-representação de determinados grupos no parlamento, bem como a distribuição estatística dos grupos sociais relevantes no Executivo e no Judiciário são exemplos de estratégias para promover a natureza inclusiva da democracia. Ainda no que tange a seu caráter inclusivo, a democracia contestatória pode beneficiar-se da presença de movimentos sociais ativos. Tais movimentos podem desempenhar a função de clarificar e canalizar em direção aos fóruns estatais as contestações emergentes entre cidadãos particulares.

Além do caráter deliberativo e inclusivo, a democracia contestatória deve contar com uma terceira condição para sua efetividade: a responsividade da polity republicana. Ou seja, é preciso que haja canais institucionais pelos quais as contestações formuladas nos debates públi- 
cos sejam efetivamente consideradas pelos agentes públicos. Há inúmeros canais por meio dos quais as contestações podem ser vocalizadas. "Eles incluem a possibilidade de escrever para um membro do parlamento, a capacidade de requerer um ombudsman para fazer uma investigação, o direito de apelar a uma corte superior contra uma decisão judicial, e prerrogativas menos formais tais como aquelas envolvidas em direitos de associação, protesto e manifestação" (idem, p. 193).

Os recursos contestatórios fazem parte do que Pettit designa como a "dimensão editorial da democracia". Conforme observamos acima, nos processos eleitorais o povo aparece como uma espécie de "autor" coletivo, ainda que indireto, das decisões públicas, mediante participação positiva na constituição de seus representantes no Estado. $\mathrm{Na}$ metáfora editorial de Pettit, do mesmo modo que um autor é o criador original dos textos publicados em determinado jornal ou revista, o povo é o criador original das políticas do Estado republicano. Porém, como em um jornal ou em uma revista, em que o texto de um autor está sujeito ao escrutínio dos editores, as criações do povo coletivo, autor da democracia, também devem estar sujeitas aos procedimentos contestatórios que dão voz ao povo particularizado. Ou seja, o povo é autor da democracia em sua expressão coletiva, indireta e positiva. Mas o ideal democrático deve compreender também a participação popular em sua expressão individual, direta e negativa. O povo não deve ser considerado apenas como uma entidade coletiva que se forma nos processos eleitorais. O povo real, que transcende os períodos eleitorais, é formado por indivíduos e grupamentos particulares que devem ter garantias para sua participação nos negócios públicos nos períodos de interregno entre eleições. Mesmo que, neste caso, a participação perca em potência, por realizar-se de modo individual ou por grupos particulares, ela ganha em exatidão, porque acontece de modo direto. O cidadão (ou grupo particular de cidadãos) afetado por determinada decisão recorre sem intermediários nos fóruns adequados para fazerse ouvir. Todavia, ainda que direta, essa modalidade de participação é de natureza negativa. Ela não é destinada à criação ou instituição positiva de algo novo. Os cidadãos participam para dizer não, para conter ou corrigir, em nome dos interesses comuns assumidos pela comunidade, algo já criado pelo povo coletivo, autor da democracia.
Na dimensão "editorial” da democracia, os cidadãos particulares participam com poderes análogos aos poderes que configuram as atribuições do editor de uma determinada publicação. Os cidadãos individuais não serão os criadores das leis ou decisões públicas, como o editor da publicação não escreverá o que será publicado. Mas os cidadãos podem contestar as leis ou decisões, do mesmo modo que o editor pode sugerir alterações no texto de determinado autor ou mesmo, em casos extremos, recusar sua publicação.

No republicanismo neo-romano, a participação política assume uma qualidade distinta das formas de participação teorizadas nos modelos participativistas e comunitaristas de inspiração neoateniense. Embora reconhecendo que uma cultura participativa disseminada na sociedade é condição indispensável para ao bom funcionamento da polity republicana, os neo-romanos sugerem que a participação política deve assumir feição positiva somente nos processos eleitorais. Fora das eleições, a participação direta dos cidadãos deverá assumir uma dimensão que é mais de proteção da liberdade individual do que de afirmação de uma concepção particular de bem. Seria ilusório definir a democracia como uma forma de governo em que cidadãos saturados de virtudes cívicas tomam em suas mãos, coletivamente, a prerrogativa de governar o dia a dia de uma república. Ademais, para os neo-romanos, a radicalização do ideal participativista em sua forma positiva não é somente uma ilusão no âmbito das sociedades modernas, ela é também uma ameaça ao delicado equilíbrio da polity republicana, uma vez que tende a alimentar certo desprezo pelas instituições representativas e pelos mecanismos constitucionais de "checks and balances".

É facilmente perceptível que o conceito de democracia contestatória afasta-se das abordagens que vêem nas eleições a condição necessária e suficiente do regime democrático. Consequentemente, os neo-romanos também não demonstram entusiasmo pela idéia de que cabem exclusivamente aos representantes eleitos pelo voto das maiorias as prerrogativas de fixar, decidir e implementar leis e políticas governamentais. Por um lado, as ações dos governantes eleitos devem ser acompanhadas de argumentos e razões que lhes assegurem legitimidade (RICHARDSON, 2002). Por outro, elas devem sempre estar sujeitas à contestação do povo não coletivo, do povo apreendido 
como a pluralidade de cidadãos particulares. Uma série de instituições e corpos intermediários entre o povo-eleitor, manifestado nas ações dos representantes eleitos, e o povo como a pluralidade de indivíduos e grupos minoritários é indispensável para assegurar o caráter deliberativo e contestatório da democracia. Enquadrando de maneira polêmica a questão, Pettit refere-se ao imperativo de "despolitizar" a democracia (PETTIT, 2004). Despolitização, no caso, significa retirar determinadas decisões de políticas públicas da alçada exclusiva dos políticos profissionais cujos centros de socialização são os partidos; políticos que têm como critério exclusivo de legitimidade os votos que são capazes de amealhar em processos eleitorais. Daí o enfático elogio dos neo-republicanos a fóruns de natureza jurídica e técnica como núcleos consultivos e decisórios da democracia, especialmente quando se trata de deliberar sobre leis e políticas que se supõem tanto mais próximas do interesse público quanto mais imunes elas estiverem da influência do jogo eleitoral. Como esclarece Richardson, "isto não quer dizer que não deva haver preocupação acerca do poder potencialmente antidemocrático das cortes constitucionais, especialmente daquelas habilitadas a anular a legislação democrática; mas não há dúvidas de que, embora sejam como facas de dois gumes, as cortes constitucionais são instrumentos essenciais da democracia" (RICHARDSON, 2002, p. 11). A título de exemplo, considere-se a política monetária levada a cabo pelos bancos centrais dos mais diversos países, bem como a legislação que configura a justiça criminal. Seria prudente, tendo-se em mira a realização do ideal da não-dominação, transferir a prerrogativa de deliberar sobre tais assuntos para políticos que não possuem outras credenciais para tratar de questões tão graves e tecnicamente complexas além da legitimidade conferida pelas urnas? No caso específico da justiça criminal, os neo-romanos receiam que a atribuição de prerrogativas aos políticos dependentes dos humores do eleitorado pode ensejar a emergência do que Montesquieu caracterizou como uma "tirania dos vingadores".

O raciocínio subjacente à demanda por despolitização da democracia parte do pressuposto de que a democracia eleitoral, embora eficiente para evitar os falsos positivos, é virtualmente incapaz de evitar os falsos negativos. Daí a necessidade de fóruns deliberativos e decisórios que prescindam do tipo de legitimidade auferida nas urnas. Trata-se de fomentar espaços legitimados por outros princípios, mormente pelos princípios da "imparcialidade" e da "reflexividade", agudamente examinados pelo historiador e politólogo francês Pierre Rosanvallon, cuja teoria da democracia, embora mobilizando outras fontes e tradições, guarda fortes afinidades conceituais com a teoria dos neo-romanos ( $c f$. ROSANVALLON, 2006; 2008). Também para Rosanvallon, a democracia não deve reduzir-se à sua dimensão eleitoral. Mobilizando um rico material sobre a história da democracia moderna, o pensador francês revela como as transformações pelas quais vem passando a democracia fazem surgir, ao lado do povo-eleitor, outras figuras da "soberania complexa", como o povo-vigilante e o povo-juiz. O aumento dos níveis de desconfiança nos representantes eleitos já não pode mais ser interpretado unilateralmente como indicador de crise e enfraquecimento da democracia, pois "a história das democracias reais são indissociáveis de uma tensão e de uma contestação permanentes" (ROSANVALLON, 2006, p. 11).

\section{ELITISMO, RACIONALISMO E DESPOLI- TIZAÇÃO}

O modelo neo-romano da democracia contestatória tem recebido crescente atenção nos debates acadêmicos no campo da teoria democrática. Como invariavelmente ocorre com formulações originais, esse modelo tem sido também objeto de críticas e objeções. Os debates na teoria política não são acontecimentos anódinos. As disputas dão-se em torno do significado de conceitos com longa história de uso, o que os torna refratários a definições consensuais. É correta a observação de Nietzsche, endossada pelo historiógrafo alemão Reinhart Koselleck, segundo a qual "todos os conceitos nos quais se concentra o desenrolar de um processo de estabelecimento de sentido escapam a definições. Só é passível de definição aquilo que não tem história" (Nietzsche apud KOSELLECK, 2006, p. 109).

Uma vertente da crítica radical à perspectiva dos republicanos neo-romanos acusa a tendência pretensamente elitista e mesmo antipopular do modelo de "democracia" derivado do ideal da liberdade como não-dominação. Graham Maddox, interpretando a antiga república romana como um modelo político essencialmente aristocrático, refere-se à "ironia" de Roma servir como estuário de idéias e valores para a reformulação de um tipo 
de republicanismo que se quer democrático. Para Maddox, o republicanismo romano "era elitista em sua essência. Ele compartilhava as debilidades da democracia grega com poucas de suas virtudes. $\mathrm{O}$ republicanismo foi inventado pela ordem do patriciado romano, que determinou a exclusão da plebe de todos os direitos civis, salvo do privilégio de lutar e morrer por sua pátria [...]. Ele era completamente aristocrático" (MADDOX, 2002, p. 421).

Esse traço aristocrático da república romana estaria presente na teoria da democracia dos neorepublicanos. Maddox afirma que Pettit nutre uma atitude acentuadamente inamistosa em relação à tradição democrática. $\mathrm{O}$ espectro da "tirania da maioria" ainda o assombra como assombrou os fundadores da república dos Estados Unidos. É certo que, sendo a democracia reconhecida como bem universal, Pettit não poderia deixar de apresentar uma visão favorável do termo. Mas o fato, prossegue Maddox, é que a concepção neo-romana de democracia não vai além de um "sistema procedimental" que revela profunda aversão a qualquer prospecto de "democracia radical". Ou seja, o modelo democrático neo-romano mantémse distante do "do espírito das instituições e procedimentos que dão pleno peso às opiniões e aos interesses aos cidadãos dos estratos mais baixos, independentemente de riqueza, nascimento ou educação" (ibidem)

Maddox concede que "a contestabilidade é o coração da democracia", como querem os neoromanos, mas argumenta que esse traço deve ser visto "em uma moldura mais ampla do que aquela apresentada por Pettit". Tomada como mero conjunto de instituições e procedimentos destinados a obstaculizar o exercício do poder, ainda que do poder aparentemente arbitrário, a democracia contestatória revela-se extremamente limitada para cumprir os requisitos de uma democracia plena, que deve ser também "promocional e organizada para a mudança radical", o que implica um razoável grau de "confrontação e oposição". Referindo-se aos neo-romanos, Maddox conclui que "os sistemas que são hostis a todos os usos do poder são certamente inimigos da democracia - o poder do povo" (idem, p. 429).

As críticas de Maddox sustentam-se em uma concepção de democracia intrinsecamente ligada ao conceito de liberdade positiva. A democracia pode ser tudo, menos indiferente à expressão do poder do povo mediante a formação de maiorias. Mas os neo-romanos, além de olharem com profunda desconfiança o poder da maioria, também revelam um radical ceticismo acerca do potencial emancipador do poder do Estado 4 . O problema, segundo Maddox, é que um Estado excessivamente limitado em seu poder é um Estado que se encontra desarmado para assegurar a liberdade no plano internacional e promover a igualdade no plano nacional, dois objetivos sem os quais não caberia falar em democracia. Assim, "a hostilidade ao poder do Estado, e a negação de que seu exercício pode ser um empreendimento comunitário dirigido à segurança e ao bem-estar públicos, pode ser um negócio arriscado [...]. A tradição republicana que Pettit tão eloquentemente defende é inerentemente conservadora e elitista" (idem, p. 430).

Essa mesma linha de ataques ao republicanismo neo-romano é ativada por John McCormick em sua releitura radical dos textos de Maquiavel. McCormick não se ocupa tanto em demonstrar a natureza elitista da antiga república romana. Seu esforço concentra-se em recuperar a identidade "populista" do pensamento de Maquiavel (MCCORMICK, 2001), e em provar que os republicanos neo-romanos partem de uma interpretação distorcida das idéias do mestre florentino para afirmar seu próprio modelo de república. McCormick acusa os neo-romanos de mal compreenderem a Sociologia dos conflitos de Maquiavel, mal compreendendo também as implicações constitucionais da concepção maquiaveliana de liberdade. O resultado disso seria uma interpretação tendencialmente "aristocrática" do republicanismo, a qual não faria justiça à natureza essencialmente democrática das idéias de Maquiavel. McCormick afirma também que esse viés aristocrático não é uma peculiaridade do republicanismo da escola de Cambridge, visto que esse traço revela-se uma constante da tradição republicana como tal. Por isso, o autor lança dúvidas sobre o valor do "retorno ao republicanismo" como corretivo para as insuficiências da teoria democrática contemporânea. Conforme polemiza: "Estou convencido de que o republicanismo, a menos que seja reconstruído quase que a ponto de desfigurá-lo, só é capaz de reforçar o que há

\footnotetext{
4 Conforme Perreau-Saussine (2007, p. 116), um dos aspectos mais marcantes do "republicanismo romântico" de Skinner é "sua relutância em focalizar o poder emancipatório do estado".
} 
de pior na democracia liberal contemporânea: o poder ilimitado que as elites políticas e socioeconômicas desfrutam à custa da população em geral" (MCCORMICK, 2003, p. 617). O problema dos intérpretes vinculados à escola de Cambridge não estaria em sua análise da tradição republicana clássica, mas em sua tendência "em mal interpretar Maquiavel por vias que enfatizam artificialmente sua conformidade com o republicanismo convencional" (idem, p. 636). Em decorrência disso, os neo-romanos negligenciam "o papel do conflito de classes na teoria de Maquiavel”, ignorando "os meios institucionais pelos quais o povo tornava as elites responsivas e responsáveis por seus atos". Além disso, eles "associam a ativa participação popular no pensamento de Maquiavel primeiramente com conquistas militares, em contraste com a política doméstica". Ademais, ao igualarem, "inapropriadamente, suas críticas à nobreza com aquelas do povo", acabam por debilitar "o papel proeminente que Maquiavel atribui ao povo como 'guardião da liberdade"”. Os neo-romanos preferem ainda enfocar "definições abstratas de liberdade às expensas de suas recomendações relativas a políticas específicas sobre como mantê-la". O fato é que embora esses republicanos usem Maquiavel para formular uma definição de liberdade que se opõe à opressão política de vários tipos, tal definição permanece "fraca com respeito à dominação social", o que resulta em um amplo "silêncio sobre o tipo de dominação doméstica do povo pelas elites" (ibidem)

McCormick argumenta que a recuperação do pensamento político de Maquiavel teria mais utilidade para a superação dos dilemas da teoria democrática contemporânea do que para reviver a tradição republicana. Ele prefere dar ênfase às tendências pró-plebéias do pensador florentino, realizando um esforço para trazê-lo para o leito do radicalismo democrático contemporâneo. Assim, a despeito do que se depreenderia da interpretação protagonizada pelos neo-republicanos, "Maquiavel defende uma república, sem qualquer ambigüidade, dominada pelo povo" (MCCORMICK, 2001, p. 311) ${ }^{5}$.

\footnotetext{
5 A despeito das críticas de McCormick ao republicanismo vinculado à Escola de Cambridge, parece-nos que a perspectiva por ele adotada, descontado o tom polêmico em que é veiculada, permanece nos quadros referenciais do
}

Enquanto Maddox e McCormick criticam a concepção de democracia dos neo-romanos por esta sucumbir aos traços mais elitistas da tradição republicana clássica e moderna, autores como Nadia Urbinati (2010) e Richard Bellamy (2008; 2009) apontam suas baterias contra o tipo de processo deliberativo que se estabelece como condição da democracia contestatória. Para ambos, um excessivo racionalismo encontra-se subjacente ao modelo deliberativo dos neo-romanos, um racionalismo que resulta em uma visão essencialmente despolitizada da democracia ${ }^{6}$.

Urbinati procura revelar as afinidades entre os ideais democráticos dos neo-romanos e uma série de argumentos típicos das tradições antidemocráticas. A autora reconhece que seria inadequado simplesmente compreender autores como Pettit e Rosanvallon no rol de opositores da democracia. Ela afirma que ambos são "amantes da verdade que são também amigos da democracia" (URBINATI, 2010, p. 66). O problema é que, para os amantes da verdade, nos momentos em que esta entra em conflito com a democracia, a segunda é sempre perdedora. Pettit e Rosanvallon, embora amigos da democracia, são "críticos internos" dessa forma de governo. É certo que a intenção de ambos seria proteger a democracia contra a politização excessiva decorrente da competição partidária e dos processos eleitorais. No entanto, a despeito de suas intenções, Pettit e Rosanvallon acabam ecoando idéias e argumen-

ideal de liberdade como não-dominação. O que de fato ocorre é que McCormick interpreta esse ideal enfatizando o papel dos setores populares em detrimento do viés tendencialmente mais "aristocrático" dos neo-romanos. Os instrumentos sob controle popular destinados a conter e responsabilizar os governantes recebem mais destaque e visibilidade na interpretação do teórico norte-americano. Ver, a propósito, Silva (2010)

6 É interessante observar que, mesmo entre os republicanos neo-romanos, há aqueles que criticam Pettit por sua insistência em apresentar seu modelo como uma "república da razão". É o caso de Maurizio Viroli, quando afirma que "as repúblicas reais não são repúblicas da razão, como Pettit tem escrito, mas repúblicas da eloqüência" (VIROLI, 2002, p. 19). Para Viroli, o projeto neo-republicano nada teria a ganhar sacrificando a retórica e a eloqüência em proveito da busca a qualquer custo por argumentos racionais publicamente expressos. Essa seria uma agenda dos teóricos da democracia deliberativa, não dos republicanos. O republicanismo, de acordo com Viroli, deve responder "incitando cidadãos e líderes políticos a aprenderem como dominar a eloqüência" (ibidem). 
tos nascidos da tradição antidemocrática, uma vez que a democracia não pode ser qualquer coisa que diminua a importância da politização de todas as questões de interesse público, politização materializada na competição aberta entre os diferentes partidos políticos.

O processo deliberativo idealizado pelos neoromanos é apresentado por Urbinati como uma espécie de antídoto à democracia, uma vez que ele apóia-se em uma noção de "julgamento" como "a reserva de imparcialidade e reflexividade, duas qualidades que podem corrigir a política do partidarismo" (idem, p. 72). A multiplicação de corpos deliberativos compostos tanto por especialistas como por cidadãos comuns traria mais dificuldades do que soluções para a democracia. A contrapartida da valorização desses corpos deliberativos seria a desvalorização dos representantes eleitos pelos cidadãos, bem como o deslocamento da centralidade das eleições. Os corpos deliberativos transmitem a idéia de que os corpos representativos são facciosos e irracionais. Eleição e representação, dois aspectos definidores da experiência da democracia moderna, são apresentados de modo acentuadamente negativo pelos teóricos neo-romanos, e a disseminação dessa visão para o público em geral levaria ao aprofundamento da crise de legitimidade das autoridades eleitas pelos cidadãos, resultando no contrário de uma solução desejável para os dilemas da democracia (idem, p. 75).

Assim, o republicanismo neo-romano não é uma perspectiva que compreende ou complementa a democracia, mas um substitutivo dela: "a tradição do republicanismo neo-romano significa antes o império da lei do que a vontade popular" (idem, p. 77). A autora afirma que os neo-romanos de hoje cumprem papel semelhante ao papel dos liberais depois da II Guerra Mundial. Se em meados do século passado liberais como Isaiah Berlin acusaram a democracia (liberdade positiva) de violar a liberdade como ausência de interferência, os neoromanos de hoje acusam-na de sua incapacidade de assegurar a liberdade como não-dominação.

No lugar do julgamento político e democrático realizado em processos eleitorais ou pelos representantes eleitos no Parlamento, os neo-romanos defendem uma noção de julgamento que se inspira nas práticas judiciais. Daí a sobrevalorização da imparcialidade como a faculdade que capacita o Juiz para um julgamento jus- to. Urbinati defende que o julgamento democrático, político por excelência, não pode basear-se na imparcialidade, uma vez que seus protagonistas são partidos e cidadãos claramente vinculados a interesses e valores particulares. Isso não impede que, de modo a assegurar a natureza coletiva das decisões democráticas, o modelo do julgamento político seja preferível ao modelo do julgamento judicial. "O julgamento político tem a generalidade (o interesse geral da comunidade política como um todo) como seu critério. O julgamento da justiça almeja em vez disso a imparcialidade na avaliação de certo fato ou de um conjunto de dados ou atos. Uma diferença crucial entre essas duas formas de julgamento é que o júri no tribunal não está envolvido no caso sob consideração do mesmo modo que os eleitores e representantes estão no (nemo judex in causa sua)" (idem, p. 81; grifos no original).

Outro crítico insatisfeito com a despolitização que decorre da dimensão deliberativa da democracia contestatória é o politólogo inglês Richard Bellamy. Em seu Political Constitutionalism (BELLAMY, 2007), Bellamy constrói um caso contra a visão do constitucionalismo como um conjunto de normas escritas cuja interpretação caberia a agentes imparciais e tecnicamente qualificados para tal. Esse tipo de "constitucionalismo legal" padeceria de graves limitações. No conjunto, "longe de proteger contra uma em grande medida mítica tirania da maioria, os controles impostos pela revisão judicial sobre o processo decisório majoritário debilitam a igualdade política, distorcendo a agenda em detrimento do interesse público, e entrincheirando os privilégios das minorias dominantes" (idem, p. VIII).

Em que pese o acento fortemente crítico das palavras de Bellamy, ele não rejeita o republicanismo neo-romano, tampouco interpreta-o como substituto da democracia. Bellamy é explícito ao anunciar que seu ponto de vista deve ser compreendido como extensão do ideal de liberdade como nãodominação. Ele está de acordo com a idéia de que o papel de uma constituição é assegurar a guarda da liberdade. O ponto de Bellamy reside no argumento de que o modo mais efetivo da constituição trabalhar em favor da liberdade é a adoção do constitucionalismo político, em detrimento do constitucionalismo legal. Nesse aspecto, o autor diverge fortemente dos propositores da democracia contestatória, que estabelecem sua clara preferência pelo segundo. 
O aspecto mais insatisfatório do modelo democrático dos neo-romanos consiste em sua crença de que a leitura pluralista do sistema eleitoral partidário competitivo contrasta com o refinado processo político orientado para a razão pública, de tal modo que a primeira pode, em certas circunstâncias, subverter o segundo. Por isso eles concluem que "o processo eleitoral democrático deve ser em certa medida constrangido e despolitizado se a razão pública deve prevalecer" (BELLAMY, 2009, p. 109). Como suporte a tal demanda, os neo-romanos "sugerem que tal despolitização produz uma afastamento da visão agregativa da democracia como reflexo da vontade do povo para uma visão mais deliberativa da democracia, que procura formular políticas que refletem razões públicas compartilhadas concernentes ao bem comum" (ibidem).

De acordo com Bellamy, os neo-romanos vêem com exagerado e injustificado pessimismo as instituições que caracterizam as democracias realmente existentes, mormente o sistema partidário competitivo e os processos eleitorais regulados pela regra da maioria. Mas o fato é que tais instituições revelam resultados bem mais satisfatórios do que aqueles decorrentes do modelo contestatório, especialmente quando se tem como metas a realização da igualdade política e a garantia da liberdade como não-dominação por meio do exercício da razão pública. $\mathrm{O}$ temor dos neo-romanos às facções impede-os de aceitar o fato de que nem todos os desacordos políticos são decorrentes de pensamentos malignos, míopes e egoístas. Recorrendo a Ralws, Bellamy critica-os por ignorarem o fato de que há desacordos políticos que decorrem "de divisões ideológicas que refletem desacordos razoáveis surgidos daquilo que ele [Ralws] chama de 'fardo do julgamento"" (idem, p. 104).

Para Bellamy, as democracias realmente existentes oferecem mecanismos muito mais adequados para o exercício da razão pública do que os mecanismos previstos no modelo deliberativocontestatório dos neo-romanos. A regra da maioria, na base de cada pessoa um voto, respeita de modo mais claro e direto a igualdade dos cidadãos. De modo a despolitizar a democracia, o modelo neo-romano investe muito na idéia de imparcialidade, atribuindo tal prerrogativa a agentes supostamente externos aos conflitos que julgam. Argumentando contra a centralidade atribuída por Pettit aos mecanismos de revisão judicial, Bellamy julga que "tanto em termos de acesso como de modo de deliberação, uma corte constitucional é mais propensa a oferecer uma forma mais parcial de razão pública do que uma legislatura que responde ao raciocínio de todo o público na base da igualdade de voto" (idem, p. 116). Ademais, poucas são as decisões das cortes que poderiam ser qualificadas como estritamente técnicas. As grandes decisões são sempre de natureza política. $\mathrm{O}$ mesmo aplica-se às decisões dos comitês de especialistas, dentre outras razões, porque até mesmo no interior das profissões há insanáveis controvérsias sobre a abordagem mais adequada a ser seguida para o equacionamento de tal ou qual decisão. Assim, "longe de ser o produto de uma abordagem mais deliberativa e objetiva de dada questão, um consenso de especialistas pode meramente resultar de uma hegemonia de certa teoria ou abordagem no interior de uma profissão" (idem, p. 117).

Para Bellamy, nada se teria a ganhar aceitando-se o ceticismo dos neo-romanos em relação pluralismo competitivo do sistema partidário eleitoral em favor de um processo mais ascético, em que a razão pública resultaria do exercício de uma pretensa imparcialidade de determinados agentes no julgamento das contestações encaminhadas pelos cidadãos. Bellamy reconhece que o republicanismo contemporâneo livrou-se de graves preconceitos que acompanharam a história da tradição republicana, mas conclui que "assim como os republicanos contemporâneos têm repudiado preconceitos anteriores contra os não proprietários e as mulheres, eles precisam também acertar as contas com a democracia. Em particular, eles deveriam tentar reforçar em vez de debilitar a regra da maioria e o sistema partidário competitivo, reconhecendo-os como meios pelos quais é promovida a igualdade política e a necessidade de políticos e eleitores responderem uns aos outros 'ouvindo a outra parte' dentro de um genuíno processo de raciocínio público” (ibidem).

\section{CONCLUSÕES}

Qual o alcance das críticas ao modelo contestatório de democracia advogado pelos teóricos do republicanismo neo-romano? Em que medida o elitismo e a despolitização podem ser caracterizados como os traços mais distintivos de tal modelo?

Vale inicialmente observar que esses aspectos "antidemocráticos" atribuídos ao modelo neo-romano provêm de perspectivas distintas e mesmo 
concorrentes entre si. Os que destacam o suposto elitismo do modelo de democracia contestatória, representados aqui por Maddox e McCormick, têm em vista um horizonte normativo em que reinaria um modelo democrático radical, caracterizado por uma intensa participação dos setores populares na esfera governamental, especialmente no que diz respeito ao estrito controle das ações dos detentores de cargos públicos. Estão ausentes dos argumentos desses críticos considerações sobre as virtudes democráticas dos políticos profissionais e sobre a eficácia da luta partidária para fazer prevalecer o interesse público. Depreende-se das análises de Maddox e McCormick uma clara preferência por uma forma de democracia participativa, com forte protagonismo popular, em que as instituições clássicas da representação política são consideradas, na melhor das hipóteses, insatisfatórias para assegurar a natureza popular da democracia.

Por outro lado, as críticas que acusam o excesso de racionalismo e a tendência à despolitização do modelo neo-romano, tais como formuladas por Urbinati e Bellamy, têm como pressuposto a defesa da centralidade da representação política e da competição partidária na definição da democracia moderna. Contra as tendências atuais de rejeição da dimensão representativa da democracia, esses autores apontam as virtudes democráticas do sistema eleitoral e apresentam o instituto do sufrágio universal como a mais eficaz realização do princípio da igualdade política nas sociedades modernas.

Em meu entender, a crítica ao suposto elitismo do modelo contestatório passa ao largo do fato de que a tradição republicana, mesmo em suas manifestações mais pró-plebéias, como em Maquiavel, jamais se desvencilhou do ideal do governo misto como o mais adequado à realização da liberdade e à prevenção da corrupção. Portanto, não é surpreendente que os teóricos neo-romanos contemporâneos, em que pese sua defesa da democracia, relutem em defender a idéia do povo como o protagonista exclusivo da república democrática. Todavia, parece-me um exagero da parte dos críticos a suposição de que o papel atribuído pelos neo-romanos ao cidadão comum é tão desprezível a ponto de justificar a atribuição de uma natureza elitista ao modelo contestatório. Ao contrário, a democracia contestatória pressupõe, para seu funcionamento, um considerável grau de ativismo dos cidadãos ordinários, quer estes ma- nifestem-se individualmente, quer coletivamente, na forma de protestos públicos e movimentos sociais. Ocorre que os neo-romanos depositam mais confiança na dimensão negativa, contestatória, da ativação popular do que na dimensão positiva, propositiva, da participação. Ademais, os neo-romanos parecem partir da crença de que, em qualquer sociedade politicamente organizada, haverá sempre uma minoria de pessoas que efetivamente ocupam os cargos públicos e uma grande maioria que estará sujeita aos impactos das decisões tomadas por tal minoria. Isso, no entanto, parece-me muito mais uma concessão ao realismo do que ao elitismo, pois é exatamente o reconhecimento do fato de tal divisão entre governantes e governados que permitirá a estes o desenvolvimento de estratégias eficazes de controle das iniciativas dos primeiros. O problema não está em evitar que o governo do Estado seja conduzido na prática por uma minoria, mas sim que tal minoria aja a seu bel-prazer, exercendo um poder arbitrário sobre o povo.

Por outro lado, as críticas ao racionalismo e à despolitização supostamente inerentes ao modelo contestatório tendem a desprezar problemas reais de regulação da vontade da maioria nas democracias modernas. Longe de ser um "mito", como sustenta Bellamy, as conseqüências potencialmente despóticas de uma vontade incontrastável da maioria fazem parte da história da democracia moderna. É verdade que, historicamente, inúmeros argumentos construídos sob o disfarce da prevenção da "tirania da maioria" acabaram por neutralizar o próprio exercício do poder legítimo e não-dominante, constituindo assim uma espécie de "falso negativo", para usar a expressão de Pettit. Isso resultaria na ultrapassagem dos limites que separam a democracia de formas antidemocráticas de governo. Mas não me parece ser esse o caso dos argumentos dos neo-romanos. Esses autores advogam o modelo contestatório como uma dimensão complementar à democracia eleitoral, não como seu substituto. Para eles, porém, as instituições da democracia eleitoral, embora sejam de fato a condição sine qua nonda democracia moderna, não são de modo algum sua condição suficiente. A seu modo, os teóricos neo-romanos apreendem a noção de soberania popular em suas múltiplas dimensões, distanciando-se do ideal "monista" de soberania, próprio da ênfase exclusiva na democracia eleitoral, por um lado, e das atualizações do ideal da demo- 
cracia direta, por outro. De modo alternativo, eles assumem o ideal de uma "soberania complexa", reconhecendo aspiração de legitimidade de uma série de corpos intermediários (comissões técni- cas, tribunais, cidadãos individuais ou reunidos em movimentos sociais etc.) na difícil tarefa de preservação da liberdade em uma república democrática.

Ricardo Silva (rsilva@cfh.ufsc.br) é Doutor em Ciências Sociais pela Universidade Estadual de Campinas (Unicamp) e Professor de Sociologia na Universidade Federal de Santa Catarina (UFSC).

\section{REFERÊNCIAS BIBLIOGRÁFICAS}

ARENDT, H. 1972. Entre o passado e o futuro. São Paulo: Perspectiva.

BARON, H. 1966. The Crisis of the Early Italian Renaissance. Princeton: Princeton University.

BELLAMY, R. 2007. Political Constitutionalism. Cambridge (UK): Cambridge University.

2009. The Republic of Reasons: Public Reasoning, Depolitization and NonDomination. In: BESSON, S. \& MARTI, J.-L. (eds.). Legal Republicanism: National and International Perspectives. Oxford: Oxford University.

BERLIN, I. 2002. Dois conceitos de liberdade. In: HARDY, H. \& HAUSHEER, R. (orgs.). Isaiah Berlin: estudos sobre a humanidade. São Paulo: Companhia das Letras.

CÍCERO, M. T. 2005. Da república. Rio de Janeiro: Ediouro. Disponível em: http:// www.ebooksbrasil.org/adobeebook/ darepublica.pdf. Acesso em: 12.abr.2011.

KOSELLECK, R. 2006. Futuro passado. Rio de Janeiro: Contraponto.

MADDOX, G. 2002. The Limits of Neo-Roman Liberty. History of Poltitical Thought, Exeter, v. 23, n. 3, p. 418-431, Summer.

MAYNOR, J. 2003. Republicanism in the Modern World. Cambridge (UK): Polity.

MCCORMICK, J. 2001. Machiavellian Democracy: Controlling Elites With Ferocious Populism. American Political Science Review, Los Angeles, v. 95, n. 2, p. 297-313, June.

2003. Machiavelli Against Republicanism on Cambridge School's "Guicciardinian Moments". Political Theory, Thousand Oaks, v. 31, n. 5, p. 615-643, Oct.
PASQUINO, P. 2009. Machiavelli and Aristotle: The Anatomies of the City. History of European Ideas, Kidlington, v. 35, n. 4, p. 397-407, Dec.

PERREAU-SAUSSINE, E. 2007. Quentin Skinner in Context. The Review of Politics, Notre Dame, v. 68, n. 1, p. 106-122, Jan.

PETTIT, P. 1997. Republicanism: Theory of Freedom and Government. Oxford: Oxford University.

. 1999. Republican Freedom and Contestatory Democratization. In: SHAPIRO, I. \& HACKER-CORDON, C. (eds.). Democracy's Value. Cambridge (UK): Cambridge University.

2000. Democracy, Electoral and Contestatory. Nomos, v. 42, p. 105-144.

2004. Depoliticizing Democracy. Ratio Juris, Hoboken, v. 17, n. 1, p. 52-64.

POCOCK, J. 1975. The Machiavellian Moment: Florentine Political Thought and the Atlantic Republican Tradition. Princeton: Princeton University.

RICHARDSON, H. 2002. Democratic Autonomy. Public Reasoning About the Ends of Policy. Oxford: Oxford University.

SANDEL, M. J. 1996. Democracy's Discontent: America in Search of a Public Philosophy. (MA): Harvard University.

SILVA, R. 2008. Liberdade e lei no neorepublicanismo de Skinner e Pettit. Lua Nova, São Paulo, n. 74, p. 151-194. Disponível em: http://www.scielo.br/pdf/ln/n74/07.pdf. Acesso em: 15.abr.2011.

2010. Maquiavel e o conceito de liberdade em três vertentes do novo republicanismo. Revista Brasileira de Ciências Sociais, São Paulo, v. 25, n. 72, p. 37-58, fev. Disponível 
em: http://www.scielo.br/pdf/rbcsoc/v25n72/ v25n72a04.pdf. Acesso em: 15.abr.2011.

SKINNER, Q. 1983. Machiavelli on the Maintenance of Liberty. Politics, v. 18, n. 2, p. 3-15. Disponível em: http:// users.polisci.wisc.edu/avramenko/Methods/ Skinner_MachiavelliAndVirtu.pdf.Acesso em: 29.abr.2011.

1984. The Idea of Negative Liberty: Philosophical and Historical Perspectives. In: SKINNER, Q.; RORTY, R. \& SCHNEEWIND, J. B. (eds.). Philosophy in History. Cambridge (UK): Cambridge University.

1990a. Machiavelli's Discourse and the Pre-Humanist Origins of Republican Ideas. In: SKINNER, Q.; VIROLI, M. \& BOCK, G. Machiavelli and Republicanism. Cambridge (UK): Cambridge University.

1990b. The Republican Ideal of Political Liberty. In: SKINNER, Q.; VIROLI, M. \& BOCK, G. Machiavelli and Republicanism. Cambridge (UK): Cambridge University.

2002. Visions of Politics. V. 2. Cambridge (UK): Cambridge University.
2007. Intellectual History, Liberty and Republicanism: an Interview With Quentin Skinner. Contributions to the History of Concepts, Oxford, v. 3, n. 1, p. 103-123.

RICHARDSON, H. 2003. Democratic Autonomy. Oxford: Oxford University.

ROSANVALLON, P. 2006. La contre-democratie. Paris: Seuil.

. 2008. La legitimité democratique. : Seuil.

ROULAND, N. 1997. Roma: democracia impossível? Agentes do poder na urbe romana. Brasília: UNB.

TAYLOR, C. 1985. What's Wrong With Negative Liberty. In: TAYLOR, C. Philosophy and Human Sciences. Cambridge (UK): Cambridge University.

URBINATI, N. 2010. Unpolitical Democracy. Political Theory, Thousand Oaks, v. 38, n. 1, p. 65-92, Feb.

VIROLI, M. 2002. Republicanism. New York: Hill and Wang. 